
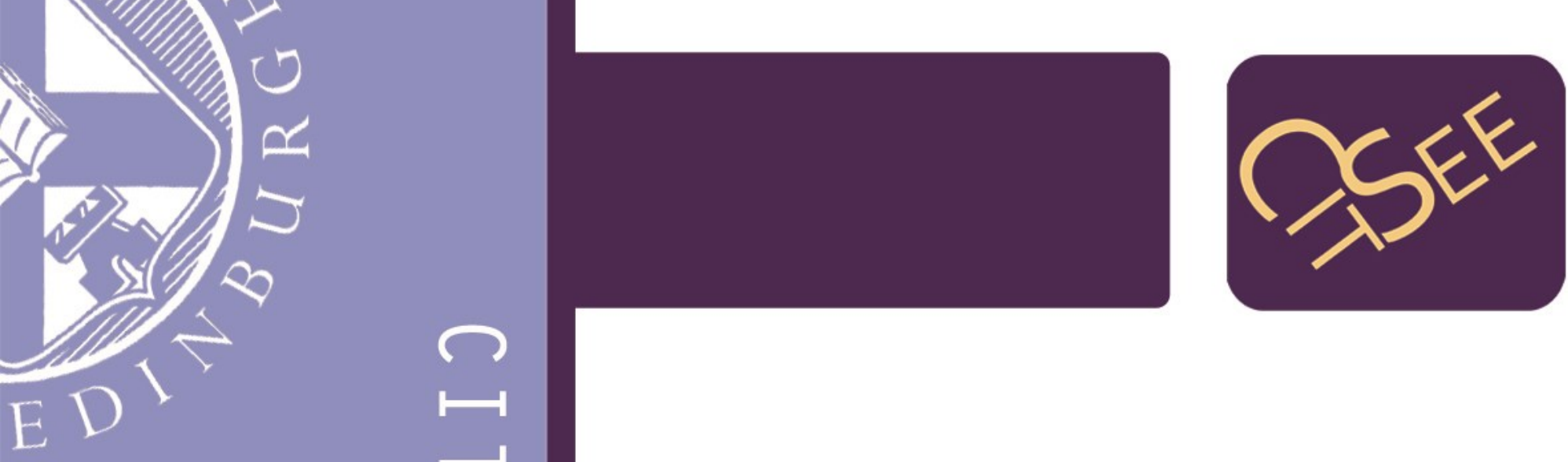

Citizenship as lived experience: belonging and documentality after the breakup of Yugoslavia

\author{
Jelena Vasiljević
}

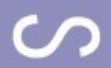

Гा

20

$\mapsto$

Гा

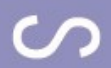

Working Paper 2014/36

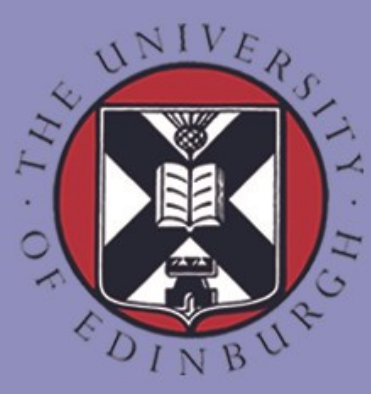

European Research Council 
University of Edinburgh, School of Law

The Europeanisation of Citizenship in the Successor States of the Former Yugoslavia (CITSEE)

Citizenship as lived experience: belonging and documentality after the breakup of Yugoslavia

Jelena Vasiljević

The Europeanisation of Citizenship in the Successor States of the Former Yugoslavia (CITSEE)

CITSEE Working Paper Series 2014/36

Edinburgh, Scotland, UK

ISSN 2046-4096 


\section{(C) 2014 Jelena Vasiljević}

This text may be downloaded only for personal research purposes.

Additional reproduction for other purposes, whether in hard copies or electronically, requires the consent of the authors.

Requests should be addressed to citsee@ed.ac.uk

The view expressed in this publication cannot in any circumstances be regarded as the official position of the European Union.

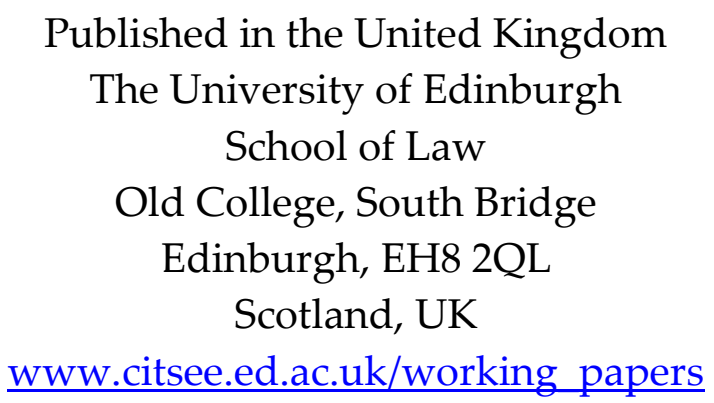

This work was supported by funding from the CITSEE project (The Europeanisation of Citizenship in the Successor States of the Former Yugoslavia), based at the University of Edinburgh, UK. CITSEE is funded by the European Research Council under the European Union's Seventh Framework Programme, ERC Grant no. 230239, and the support of the ERC is acknowledged with thanks.

For information about the Project please visit the project website at $\underline{\text { www.citsee.ed.ac.uk }}$ 


\title{
Citizenship as lived experience: belonging and documentality after the breakup of Yugoslavia
}

\author{
Jelena Vasiljević, University of Belgrade and University of Edinburgh ${ }^{1}$
}

\begin{abstract}
Citizenship is usually thought of in terms of legal and political parameters setting the conditions for individuals' statuses and rights, and so has been the case in its application to the post-Yugoslav context. With the primary interest in the "topdown" perspective, citizenship has been described as a tool with which new states regulated their respective citizenship bodies. But, equally, by granting us documents (passports, birth and marriage certificates, IDs, etc.) which connect us to a wider community, and by employing an array of ethnic, cultural and state symbols, citizenship instills us with a sense of belonging, membership and identity. Furthermore, through our enacting of rights and duties of citizenship, it becomes an inextricable element of our everyday experience. It is especially when questioned and contested that citizenship plays a significant role in how we perceive ourselves, how we appear to others and how intergroup relations are mediated. This paper focuses on personal narratives that reveal lived experiences of the triangular relationship between citizenship, identity and (national) belonging in the post-Yugoslav space. Its aim is to shed some light on a less examined perspective of citizenship transformations, and to complement the currently existing literature on citizenship regimes in the post-Yugoslav states with a bottom-up approach that treats citizenship in its identity-forming and recognition-bearing social role.
\end{abstract}

Keywords: citizenship, post-Yugoslav states, life stories, belonging.

\section{Introduction}

This paper explores some of the personal narratives revealing lived experiences of the triangular relationship between citizenship, identity and (national) belonging in the post-Yugoslav space. Drawing on the established body of research on changes of citizenship policies after the breakup of Yugoslavia, it sets to explore the lived dimension of politico-legal regulations of citizenship in post-Yugoslav states.

Citizenship is usually thought of in terms of legal and political parameters setting the conditions for individuals' statuses and rights. But, equally, by granting us documents which connect us to a wider community, and by employing an array of ethnic and state symbols, citizenship instills us with a sense of belonging,

\footnotetext{
1 Jelena Vasiljević, Research Assistant at the Institute for Philosophy and Social Theory at the University of Belgrade and CITSEE Research Fellow at the School of Law, University of Edinburgh. Email: jelena vasiljevic@yahoo.com.
} 
membership and identity. Furthermore, through our enacting of the rights and duties of citizenship, it becomes an inextricable element of our everyday experience. It is especially when questioned and contested that citizenship plays a significant role in how we perceive ourselves, how we appear to others and how intergroup relations are mediated.

The breakup of Yugoslavia led to the disintegration of the two-tier (federal and republican) Yugoslav citizenship regime and in its place the new states' regimes were instituted. This process had an enormous impact on many lives, and, as the existing scholarship often points out, some groups were especially vulnerable and disadvantaged in obtaining their statuses and rights, like Roma, ethnic minorities, but also "groups" that were formed as a result of the state breakup and ensuing war, like the so-called erased in Slovenia or war refugees in Serbia, Croatia or Bosnia (see for example Dedić, Jalušić and Zorn 2003 and Deželan 2012 on the erased in Slovenia, Vasiljević 2012 on citizenship status of refugees in Serbia, Sardelić 2013 on Romani minorities in post-Yugoslav space). But also, this complex process of citizenship regimes' transformations affected the lives of many others, often unnoticed in literature on citizenship in post-Yugoslav states, who either experienced various difficulties in regulating their citizenship statuses, or found themselves having the "wrong" citizenship or living in the "wrong" new state, or who decided to migrate and settle in what they perceived to be their kin-states (often again facing problems with either obtaining citizenship or experiencing various forms of discrimination). This paper sheds light on several life stories of those whose lives were dramatically shaped by citizenship policies, politics of belonging and dynamics of self-ascription and external ascription of identities. These personal narratives are analyzed through identification of several dominant themes illustrating interconnectedness between personal destinies, legal predicaments and group belonging.

\section{1. Looking at the post-Yugoslav landscape through a lens of citizenship}

Recently, we have seen a growing scholarship systematically using the concept of citizenship as a powerful magnifier for many different processes in the postYugoslav region (see Shaw and Štiks 2013). Although usually absent from scholarly discourse in (post) Yugoslav studies - perhaps erroneously considered as a predominantly legal and technical concept - citizenship lends its explanatory power to many insightful analyses of different socio-political processes that have shaped the region, ranging from nation-building, minority and territorial politics to questions pertinent to issues of gender, religion, ethnic and sexual minorities (see Žilović 2012, Stjepanović 2012, Zaharijević 2013, Đorđević 2013, Bonfiglioli 2013, Kahlina 2013, Radović 2013 etc.).

Citizenship, in its manifold meanings, could be a very useful framework for understanding a political community's dynamic - its inclusion/exclusion criteria, maintenance of geographical and symbolic boundaries, internal management of community's groups, political participation and (self) organization of citizens etc. 
Citizenship indeed manifests itself as "social glue" that keeps a political community together (Shafir 1998: 3).

Citizenship is usually thought of in its legal and formal aspect, and so has been the case in its application to the post-Yugoslav context. With the primary interest in the "top-down" perspective, citizenship - and the accompanying, very useful organizing notion of "citizenship regime" ${ }^{2}$ - has been described as a tool with which new states regulated their respective citizenship bodies: through the processes of citizens' "inclusion (or invitation), exclusion, and self-exclusion" (Štiks 2013), through shaping and designing new ethnic arrangements (Koska 2012; Deželan 2012; Vasiljević 2012), through adapting constitutional frameworks to internationally imposed consociational arrangements (Spaskovska 2012; Sarajlić 2012) etc. Citizenship - in the formal and legal sense of the word - thus proves itself to be the ultimate fortifier of political visions, a powerful tool for designing overall national policies.

However, since in principle these institutional designs aim to manage and control the population, they have immediate effects on people's everyday lives. As was already pointed out, many case studies, depicting citizenship regime changes in all the post-Yugoslav states, have shown us how sizeable groups of people were heavily affected - by being left without documents, with difficult access to basic citizenship rights, or with diminished political and voting rights. Therefore, as it will be argued, citizenship is always - even when confined to its procedural and legal dimension - inextricably attached to everyday life experiences, to general feelings of acceptance and belonging, finally, to possibilities of realization of full human and political capacities.

It is precisely this "lived dimension" of citizenship that I want to focus on, by exploring several narratives of people whose life stories were shaped, in great measure, by changing citizenship regimes and politics of nationhood and belonging. In the next part, I will briefly outline which groups are generally considered as "affected" in this sense - in the new post-Yugoslav states - in order to clarify the link between citizenship and vulnerability. However, in this paper I do not attempt to represent the "voices" of these groups, let alone to gather a representative sample of any kind, as I will further explain. I aim to shed some light on the less examined perspective of citizenship transformations, and to complement the currently existing literature on citizenship regimes in the post-Yugoslav states with a bottom-up approach that treats citizenship in its identity-forming and recognition-bearing social role.

\footnotetext{
2 "By 'citizenship regime' we generally mean the citizenship laws, regulations and administrative practices regarding the citizenship status of individuals but, in addition to that, it also refers to existing mechanisms of political participation. More precisely, a citizenship regime is based on a given country's citizenship legislation defining the body of citizens (i.e. who is entitled to citizenship and all duties and rights attached to that status), on administrative policies in dealing with citizenship matters and the status of individuals, and, finally, on the official or non-official dynamic of political inclusion and exclusion." Shaw and Štiks 2012: 311.
} 
The third part of the paper will anchor the understanding of citizenship used in analysis of the personal narratives that follow. I want to stress the identitarian and the lived aspect of citizenship and to show how inseparable they are from its formal and legal aspects. To this point I will introduce the possibility of using Maurizio Ferraris' concept of "documents as constitutive of social reality" in understanding how interrelated citizenship and sociality are.

Finally, the fourth and the main part of this paper presents a short selection of personal narratives portraying very different encounters with the issues of citizenship and belonging in the aftermath of the Yugoslav breakup. The used material is organized and analysed through thematic clusters with the intention to highlight different aspects and multiple dimensions of lived experiences of citizenship.

\section{Affected groups and individuals}

A citizenship regime presupposes a certain stability, it defines rules and principles governing the processes of acquisition and loss of citizenship, it delineates the body of citizens who exercise their rights and duties, and who form certain types of relationships with the state, the state institutions and fellow co-citizens. But when the citizenship regime is questioned, or in the process of remaking, or substituted with another regime, rules and principles disintegrate, as well as the structure of the citizenry, leaving many outside of its boundaries, denied of their citizenship status. This is what happened when Socialist Yugoslavia (SFRY) disintegrated. SFRY was characterised by a specific two-tier citizenship regime which endowed every citizen with both federal and a republican citizenship: every citizen was, upon birth, registered in one of the republic's registries, thus receiving republican citizenship which simultaneously meant Yugoslav citizenship as well. Although, different Yugoslav constitutions defined differently the issuing procedures and the role of issuing authorities, republican citizenship was the one issued upon the birth, its possession meant automatically the possession of the federal, Yugoslav citizenship. However, the exact legal relationship between the two citizenships, and the hierarchy between them, was never quite clear, as different legal scholars argued differently about the issue (see for example Pejić 1998, Rakić 1998). More importantly, for the citizens of Yugoslavia, their republican citizenship meant very little, if anything, since - by the virtue of being Yugoslav citizens - they were all guaranteed the same rights in all of the six Yugoslav republics, regardless of the republican citizenship they held. The lack of any concrete meaning and purpose for republican citizenship resulted in many Yugoslavs migrating from one republic to another, without changing their republican citizenship: they were neither required to, nor they had any practical reasons to do it (not to mention that they were often oblivious of it).

Things dramatically changed when the republics became sovereign states; the republican citizenship became the basis for determining new citizenries and 
establishing new citizenship regimes. The immediate effect of these changes was that many found themselves having the "wrong" citizenship, i.e. not being registered as citizens in states they resided and lived in. Depending on the citizenship laws and concrete political measures, different ex-Yugoslav republics dealt differently with this problem. The most notorious case in this respect and the one that has been very well documented was the case of "the erased" in Slovenia (Dedić et al. 2003). ${ }^{3}$ But there were many others who experienced the bitter destiny of either not having the right documents, or finding themselves living in the "wrong" country, since the general citizenship agenda of the post-Yugoslav countries followed ethno-national principles.

The existing case studies of citizenship regime changes in the post-Yugoslav states all point to the fact that certain groups of people proved to be especially vulnerable in these processes. Probably the largest such group in the whole region were war refugees. ${ }^{4}$ Paradigmatic was the case of the status of refugees in Serbia country recipient of the largest number of refugees - who were, for political reasons, denied Serbian citizenship for a long period of time, or who faced extreme difficulties in regulating their statuses, basic rights, whose rights over property in countries of

\begin{abstract}
${ }^{3}$ At the moment of Slovenia's declaration of independence, in 1991, some 200,000 residents of Slovenia held citizenship of other republics of former SFRY. Those nationals of other republics, who had permanent residence in Slovenia, were allowed to acquire Slovenian citizenship on condition that they applied for it within six months of the new Citizenship Act coming into force, which meant by December 26, 1991. Those who failed to apply on time, or were refused Slovenian citizenship came under the jurisdiction of the Aliens Act. "However, the Aliens Act did not provide for the transitory status of SFRY nationals who did not apply for Slovenian citizenship or were refused it, so these persons became de-facto foreigners illegally residing within the territory of Slovenia and were obliged to settle their status ... The situation of these persons radically deteriorated when, on February 26, 1992, the administrative bodies transferred their records from the register of permanent residents to the register of foreigners, in accordance with the second paragraph of Article 81 of the Aliens Act. The most serious consequence of this data transfer was not the fact that these persons became foreigners in Slovenia - they also lost their habitual resident statuses, meaning that, effectively, they were erased from the register of Slovenian residents. The erasure was implemented »by right of office, " and the erased individuals were not notified in any way of this move." (Dedić et al. 2003: 46-48). It is estimated that approximately 18,300 people were
\end{abstract} thus erased.

${ }^{4}$ Although war refugees were particularly affected with citizenship related problems - given the fact that they were forced to seek refuge in another country - the problem of internally displaced persons (IDPs) in this context should also be considered. This is especially the case in Serbia, which is still the country with the greatest number of refugees in Europe, with officially some 57,000 persons still holding this status, and with additional 210,000 IDPs (http://www.b92.net/eng/news/society.php?yyyy=2013\&mm=06\&dd=20\&nav id=86697 last accessed 25 April 2014). IDPs in Serbia fled from Kosovo and are not considered as coming from a different county. However, their properties and possessions, as well as their previous citizens' statuses are linked to a territory which is now ruled by a different citizenship regime. Moreover, authorities in Serbia insist on the policies of their return to Kosovo, despite the fact that the majority of IDPs are not able or not willing to do so, due to political circumstances. The political stance of the Serbian government has thus been the great obstacle for their integration in Serbia and for their achievement of full citizens' rights (see more in UNHCR and Praxis 2007). 
origin were put in question, due to non-acceptance of dual citizenship etc. (see Vasiljević 2012, Koska 2012, Đorđević 2013).

Many studies have also pointed out the disadvantaged position of the Roma population throughout the former Yugoslav countries, who, due to their traditional way of life and frequent migrations across the Yugoslav republics often faced statelessness, and whose conditions further deteriorated during the wars and after the consolidation of the new boundaries took place (Sardelić 2013).

Another category often said to be in an unfavourable position is national and ethnic minorities. Due to ethno-national politics in the region, then especially due to wars and fighting over territories and boundaries in Croatia and Bosnia, historical minorities, as well as groups of people who were turned into minorities in different regions, experienced many exclusionary measures resulting from ethnically designed citizenship policies. Many case studies on citizenship after Yugoslavia accentuate precisely this dimension of discrimination embodied in citizenship (see the volume edited by Shaw and Štiks 2013). ${ }^{5}$

In addition to all the mentioned 'groups' - the erased, the refugees, Roma, minorities - we could certainly add many others who directly felt the consequences of changing citizenship regimes and policies: so called mixed marriage couples and children from mixed parentage, ${ }^{6}$ people living close to borders, dual nationals, diaspora etc. I intentionally put the word groups in inverted commas, because these categories cannot be treated as proper groups in any analytical sense - there is no unifying criterion determining their group status; some are considered historically as groups, some were formed into groups due to circumstances, some have group identity, others do not etc. But, as categories of description, taken together, they help us understand and map the question of vulnerability pertinent to changes affecting post-Yugoslav citizenship statuses.

\subsection{A note on methodology}

However, the aforementioned categories still do not exhaust all the instances of citizenship related problems many individuals faced in the aftermath of the Yugoslav breakup. They are mostly helpful when looking at concrete country case studies and their specific constitutional and legal changes to notice discriminatory practices and patterns of vulnerability. But the issue of lived experiences of turbulent citizenship changes goes beyond clear-cut cases. The complex dynamics of the state dissolution

\footnotetext{
${ }^{5}$ Jasminka Dedić, in a more general account, points out that "Citizenship itself embodies legalized discrimination, since it presupposes a legitimate distinction between citizens and non-citizens" (Dedić et al: 25).

${ }^{6}$ The most serious conflicts occurred in places with an ethnically and religiously mixed population. People fleeing from conflicts sought refuge where their co-ethnics lived, when possible moving to their "ethnic kin states". However, families of so called mixed origin found themselves in an especially difficult position, rarely being able to find secure refuge with any of the ethnic groups involved in the conflict.
} 
and formation of the new states provoked numerous consequences: people started to migrate, mostly seeking safety, wanting to move to what they perceived to be their "kin" states; many became diaspora, many faced difficulties when maintaining contacts with their relatives and friends from other republics, many families temporarily or permanently split etc.

Therefore, in order to fully grasp the lived and the "intimate" dimension of citizenship we should think across and beyond specific (group or country) case studies, which is why I decided to concentrate on a diverse set of personal narratives - depicting various situations of citizenship related problems - and to comment on them, not as being representative of certain affected groups or of a concrete set of (disputable) measures, but as exemplary of specific themes and motifs which remind us that citizenship is always something lived and embedded in social relations.

The idea was to find stories that would illustratively depict the inextricable link between citizenship and social realities we find ourselves in. I was looking for different stories depicting individual struggles with citizenship related problems stretching from trying to obtain "the right" documents to securing one's place, membership and rights within a political community - that took place against the backdrop of one (Yugoslav) citizenship regime's decomposition and the institution of new regimes.

Material was mostly obtained through interviews I conducted between December 2013 and March 2014, in Sarajevo, Ljubljana and Belgrade. In choosing my interviewees I was principally guided by the aim of showing diverse citizenship related predicaments many people found themselves in after the Yugoslav breakup. I was not aiming to gather "representative stories", of individuals belonging to groups already known to have been marginalized and discriminated against in obtaining their citizenship statuses and rights, but was rather inclined to search for individual examples that might offer interesting insights into the wider social importance of citizenship as a personal experience.

I used unstructured interviews, asking open-ended questions allowing my collocutors to respond freely and in depth about their experiences of citizenship. I wanted them to tell me the portions of their life stories, anchored in the "citizenship related event", which was previously known to me, and which I stressed as my main point of interest. The interviews lasted between 45 and 60 minutes, and resulted in life narratives, where the interviewees presented both what happened to them and how they lived and still live through these experiences. This reconfirmed that narrative is "the discourse unit that presents both what happened, that is events in the past, and what they mean, that is the evaluation or moral significance of these events" (Linde 2009: 221).

Instead of presenting one story after another, I chose to compress, combine and cluster them, so specific themes - rather than life stories as such - could emerge and inform us of various ways in which citizenship, especially when questioned and disputed, can be lived and experienced as a social conditioner. In addition to stories collected through interviews, I used some of the stories previously known to me - 
which I found extremely illustrative for this purpose - with their "author's" knowledge and consent. I also made references to previously published material containing important and detailed personal accounts of the erased in Slovenia (Dedić et al 2003). All the personal names mentioned have been altered.

\section{Citizenship: from legal concept to social object}

\section{1. Elements of citizenship}

Citizenship is one of those notions encircled with an abundance of definitions, disciplinary approaches and conceptual traditions of thinking. Whether we think of it through its two major paradigms - legal (citizenship as rights) and republican (citizenship as political participation) (Pocock 1998) - through its different national traditions (Brubaker 1992), through the evolutionary paradigm of citizenship rights (Marshall 1998), or through contemporary trends of post-nationalism, cosmopolitanism and deterritorialization (Soysal 1998, Isin \& Turner 2007, Bauböck 2010), citizenship always points to its constitutive parts: political community, membership, conditions of membership, rights and duties of members. As Wiener rightly points out, it is above all a relational concept comprised of three constitutive elements: individual, community, and the relation between them (Wiener, 1999: 199). To this we might add another two elements: relations between citizens themselves, and relation between citizens and non-citizens. This reminds us that citizenship (or citizenship rights and duties) is always enacted and lived in a context with other people - interconnecting with other social relations - and also, that it is contained within certain boundaries, usually boundaries of a political community, which may be both external and internal. ${ }^{7}$

As Shaw and Štiks (2012) noted, many authors favour a tripartite definition of citizenship basic elements. So for example, Joppke (2007) makes a distinction between status, rights and identity, Wiener (1994) discusses rights, access and belonging, Bellamy (2004) distinguishes between citizenship as rights, belonging and participation etc. From this we may observe that, besides being a political and legal concept, citizenship is always an equally socially and culturally embedded practice as well. Moreover, these elements are very well interconnected and mutually dependent: rights and formal statuses we hold are immersed in socio-cultural contexts and political realities we live in. This is equally true even for the most technical features of citizenship - 'papers' we hold which identify us and enable us to travel.

\footnotetext{
7 Even when citizenship policies extend to encompass "co-ethnics" in other polities (Brubaker 1996), when we can speak of "overlapping" polities and "constellations" of citizenships (Bauböck 2010), the boundaries are still implied and they separate citizens from non-citizens.
} 


\subsection{Social dimension of citizenship documents}

The "documental" aspect of citizenship - identification cards, passports, visas, and other authorized "proofs" of our identity - has usually been analyzed, in academic writing, with reference to the evolution of state authorities, mechanisms of control and registration of population, state policies, and international policies controlling population movements, migrations etc. - in other words, inform a top-down perspective (Torpey 2000, Groebner 2007).

Torpey's important work on the history of the passport (2000) is actually the history of how the modern nation-state obtained exclusive monopoly over "the legitimate means of movement". He underlines two very important and interrelated observations: nation-states could not have been institutionalized without obtaining full control over the regulation of people's movements, and this would not have been possible without the introduction of the complex system of documents. By effectively "embracing" its population, the nation-state posited itself as the only legitimate authority in a position to allow or restrict movement of individuals (5). The control of the movement of citizens, and non-citizens alike (as well as the control over the distinction between the two categories), was made possible through documents, primarily passports. ${ }^{8}$ This regulation of movement proved to be essential for the formation of modern states - "it contributes to constituting the very 'state-ness' of states" (6).

He is right to note that "imagining the nation" would have been a futile social and political process had it not been followed by the processes of codifications and documentations: "states' monopolization of the right to authorize and regulate movement has been intrinsic to the very construction of states ... procedures and mechanisms for identifying persons are essential to this process, and ... in order to be implemented in practice, the notion of national communities must be codified in documents rather than merely "imagined'" (6). Torpey makes a more general claim about identities and documents, which I find very true, but one-dimensional at the same time: "Too frequently in recent academic writing, identities have been discussed in purely subjective terms, without reference to the ways in which identities are anchored in law and policy ... identities must become codified and institutionalized in order to become socially significant" (13).

However this may be true, we could invert the argument and also claim: the institutionalization and codification of legal statuses (identities) and rights, in academic writing, have been usually discussed in purely objective terms, without reference to ways in which statuses and rights are anchored in personal experiences, affects and social contexts. Precisely this point can be found in Stef Jansen's paper (2009) on "geopolitics of entrapment", analysing regulations of cross-border mobility

\footnotetext{
${ }^{8}$ A visa system is another layer of control and management of populations' movements. On how nation-states use visa restrictions to maintain and reinforce existing inequalities, by controlling access to foreign spaces, see Neumayer 2006.
} 
as experienced by citizens of Bosnia-Herzegovina and Serbia before the visa liberalization regime took place. ${ }^{9}$ Building on the idea of documents becoming part of and shaping individuals' subjectivities and affects, looking at "interactions between documents and persons" (Navaro-Yashin 2007: 80), Jansen takes on issues of mobility, state sovereignty, and control of citizens' mobility from the perspective of the affected individuals, taking an ethnographic approach, asking how the documents are becoming part of persons, and how persons are "coming into being in particular ways through them [documents]" (816). For instance, he shows how the collective experience of visa queues in front of EU embassies - as "embodied togetherness through humiliation" (818) - coupled with "everyday engagements with geopolitical hierarchies" (817) (living in countries aspiring for the EU accession) form social relations that produce "entrapped subjects".

Ethnographies like this one complement the notion of citizenship, too often regarded solely as legally and politically regulative, with a subjective dimension, reminding us that policies and laws are always conditioned by and experienced through social relations. On the other hand, as the following paragraphs aim to show, social relations and social institutions are at the same time preconditioned on the documents (citizenship documents as well), thus showing us how sociality and documentality are in fact inseparable.

\section{3. Documentality: citizenship as "social object"}

If citizenship cannot be thought of only as a legal concept, or reduced to either political, economic, or social dimensions, but rather requires an approach that can take into account its manifold aspects and meanings, should we also think of its ontology in a more abstract, conceptual manner? I found it interesting to think of citizenship, and especially its constitutive role in the production of social relations, through Maurizio Ferraris' work on documentality and his theory of social objects (2013). I will sketch it here, in very brief and rudimentary basis, with the aim of showing what it means to treat citizenship as a social object.

Ferraris starts by categorising objects into natural, ideal and social objects. Natural objects are tangible and they exist in space and time independently of subjects. Ideal objects exist outside space and time and depend on subjects - for instance, a triangle is an ideal object. Finally, social objects - a matter of his and our concern - are bound by space and time, and also depend on subjects.

Social objects are, according to Ferraris made of inscriptions, be it on paper, on a computer, or only in our heads - in a way that they are all documented, or defined as being documentable. They inhabit the social world - in fact, they are so constitutive of the social world that Ferraris calls this theory of social world documentality.

\footnotetext{
${ }^{9}$ On visa liberalization process in the countries of the Western Balkans and how it affected the status and rights dimension of citizenship in the region see Kacarska 2012.
} 
"The ontology of social objects is made up of traces, registrations, and documents, and it manifests itself in those bits of paper or plastic that we hold onto more carefully in our wallets, and then in the mass of registrations that fill up computers, archives, cell phones, and banks" (ibid: 1). Following from this, Ferraris equates social objects with inscribed acts (object = Inscribed Act), wanting to imply that social objects (those traces, documents written on a paper or a piece of plastic) are in fact social acts, in a sense that they take at least two persons to exist and that they are characterized by being written (or registered) on a medium. These inscriptions constitute "the conditions for the possibility of social objects" (ibid: 4).

In other words, although social objects are not tangible like natural ones - they are actually social relations, involving at least two persons - the condition for their existence is that they are registered, documented. Their documentality precedes their ideational form and actually conditions their very existence. Ferraris then gives examples of social objects: marriage, divorce, adoption, a prison sentence, money etc. We are accustomed to think of them as belonging to social and ideational worlds exclusively, but Ferraris argues that they would be unimaginable without being registered, confirmed on documents, archived - to this I would add: even based on certain rules and regulations which would also be nonexistent if not written down and documented. Even though not mentioned as an example, there is no doubt that citizenship is one such social object, that certain acts are inscribed in it, and that it owes its existence and its power to documents proving it, explaining its scope, or denying it.

Now, why is that important and what does it mean that citizenship is a social object? Ferraris insists that without documents - without registration of some kind there would be no society at all. Society is founded on social institutions and all of them are social objects, conditioned on being registered - and that is why documents, which register social institutions and allow them to be, are so central for the lives of persons and their interpersonal relations.

The social world is, therefore, comprised of objects that exist only because we believe they do - and our belief is grounded in the existence of documents which purport and vouch for the existence and meaning of social objects. That goes for all social institutions and roles, and I find it definitely applicable to citizenship as well.

Claim that the "inscriptions are decisive in the construction of social reality" (121) tantamount to "weak textualism", as Ferraris calls his revision of Derrida's famous idea, claiming that "there is nothing social outside the text" - wanting to imply that inscriptions are not constitutive of all reality, but they do make conditions for our social reality. In other words, there is no social outside the documents. Our social roles, relations, identities are dependent on inscriptions; the way we "officially" belong to a group, exercise our rights, feel accepted and feel part of a larger society - all the indispensable elements of citizenship - depend on our documents claiming and validating these elements. That is why Valentin Groebner (2007) is right when he claims that "Identity papers constitute our personal history; 
cartes d'identité are who we are" $(7,8)$; without them we feel we have lost our identity, and are being denied recognition of who we are.

The following stories illustrate how very constitutive of social relations documents may be, but also how personal experiences, emotions and subjectivities are equally constitutive elements of citizenship - complementing documents officially purporting it.

\section{Citizenship and belonging after Yugoslavia through personal narratives}

As Idro Seferi, a young journalist from Kosovo, now living and writing from Belgrade, recently wrote for Al Jazeera: "It is always better to have two passports you can never know who will hate whom and which ruler with what right will block people and set him(her)self as the owner of their destiny". ${ }^{10}$ He wrote this in an article based on a personal life story, depicting, among other things, troubles his family had to go through to obtain a German visa so they could visit their son living in Germany. Stories like this one are everywhere to be found, and not only in the exYugoslav space: frustration, disbelief, a feeling of deprivation because we are lacking documents that render us human, because we are not recognized for what we are, but rather for what we are perceived to be, limited and bounded by ways others identify us, either through pieces of paper we carry as a "paper doppelgänger, descriptions of what we also are" (Groebner 2007: 8), or by perceiving and fixing some of our features, like language or place of origin, as the ultimate designator of our belonging.

What follows is a collection of excerpts from various life stories that could be taken as a testimony of how citizenship sometimes sets the conditions for our social relations and how its identitarian and belonging aspects - inseparable from the notion itself - defines who we are socially.

\section{a) Blatant case: deprivation of citizenship as deprivation of existential social ties}

When we think about citizenship related problems and individual tragedies in the immediate aftermath of the Yugoslav breakup, the first thing that comes to mind is probably the issue of the "erased" in Slovenia. This is because it represents a case where citizenship is thought of in its immediate sense, as a formal link between an individual and a state, materialized in a personal document like passport or ID. So the "erased" represent a blatant case of deprivation of citizenship of some 18,300 people, due to the enforcement of a new citizenship regime that corresponded to new political agenda in independent Slovenia. ${ }^{11}$ Apart from the "obviousness" of this case, it is also very well documented both as a legal and political case study and as a

\footnotetext{
10 "Vize za svadbe i sahrane", 18.12.2013, http://balkans.aljazeera.net/blog/vize-za-svadbe-i-sahrane last accessed on 10 April 2014.

11 See footnote 3 .
} 
collection of personal narratives. ${ }^{12}$ Therefore, I will start by pointing to some of the already existing testimonies, the common thread to be found in them, and then complement that with an interview with someone who was not erased, but very well might have been.

The most peculiar thing about the politics of erasure was that it was almost a clandestine operation, it was not publicly announced, people were not informed of the possibility of the erasure, so the erased people learned about their predicament only by accident, each on a different occasion: some wanted to extend their driving licences, others were looking for a job, some inquired about their health insurance... and they were suddenly told their documents were no longer valid and that they had to declare themselves to authorities as foreigners. People could not mobilize for their cause - since they were not aware of the systemic nature of the process - and they all, each on their own, received the news with disbelief, and a feeling of helplessness and isolation.

The shock people experienced can be illustrated by the story of a woman who found out she was not a citizen upon her wish to register her newborn. She was born and raised in Slovenia, to a Slovene mother and a Serb father, married to a Slovene citizen. All of a sudden she found herself in the status of foreigner. This meant she would have to ask for temporary residence first, and then after couple of years, for permanent residence. The problem was that for a temporary residence the passport of the country "of origin" was required. Many of the erased, of course, did not have other passports since they had lived in Slovenia practically all their lives. Asking for a passport from another ex-Yugoslav republic (in which one may have been registered as a citizen) was extremely complicated due to the wars and often nonexisting family and official ties with other republics. The case of the aforementioned woman was resolved in such a way that she managed, through personal connections, to declare residence in Croatia which helped her obtain the Croatian passport, with which she finally declared residence in a country where her children and husband were recognized as citizens: "So that I could finally become a human being at the age of forty" (Dedić et al. 2003: 106). The collection of testimonies of the erased is full of hard-to-believe and yet true stories: people being deported even when not having documents of any other country, separated from their families, and denied all their rights including the right to healthcare, pensions, and property ownership.

Common motifs that emerge in all of the testimonies are feelings of abandonment and loss of all communal ties. Even when the erasure became known, and after the Constitutional court of Slovenia ruled the erasure unconstitutional, in 1999, almost no media and NGOs wanted to deal with the issue. The erased were thus left to themselves, abandoned by the community they lived in (in most cases all of their lives). Attached to this was the profound feeling of loss of all social ties people felt as if they did not belong to anyone anymore. The community in which

\footnotetext{
${ }^{12}$ It is especially worth mentioning the work of Dedić, Jalušić and Zorn (2003). In a chapter written by Jelka Zorn some 21 in-depth interviews are presented.
} 
they had lived rejected them, as if the administrative procedures and pieces of papers had such a great influence on how the wider community would react. As one interviewee said: "Everybody in Brežice and Cerklje knew that I had been expelled, all of my neighbours, but nobody wrote a letter or asked why. They could have explained that they knew me and that I was okay, that I was not an aggressor."

Aggressor is not an odd choice of word in this testimony, given the underlying ideological framework that actually might explain the lack of public reaction and empathy with the problems of the erased. The great majority of the erased were of Bosnian, Serb or Roma ethnicity. They were seen as belonging to the Balkans, the Orient, affected by the war mentality of which Slovenia was allegedly free (on the orientalising of the Balkans in Slovenian discourse see Deželan 2012). This was especially the case for Serbs who were former JNA (Yugoslav People's Army) officers and were targeted in public as wrongdoers and aggressors, which was used to justify their expulsion from the body of citizens.

I discussed the issue of the erased with Blažo, born and raised in Slovenia, whose parents are Serbs from Bosnia, but have lived in Slovenia since the early 1960s. Blažo initially held a Bosnian republic citizenship, given to him at birth, based on his father's citizenship. ${ }^{13}$ After the declaration of independence they applied for Slovenian citizenship and got it on time, before the erasure took place, only because he was insisting on it. His parents were reluctant because they did not see the point of applying for citizenship - they had lived their whole working lives in Slovenia, earned their pensions there, bought their house - they were so sure of their status that they could not imagine any consequences of failing to apply on time for the citizenship of a newborn country. As we know now, they were terribly wrong, but their understanding of the matter is exemplary of how most of the erased actually felt about the issue.

After obtaining Slovene citizenship, Blažo's family situation was much more favourable than the situation of most families of Bosnian origin living in Slovenia. I asked him if they ever had any troubles during those times, whether they had ever been discriminated against because of their background. His answer was interesting: they never faced any concrete problems, but they would often found themselves in a company of friends and co-workers discussing "southerners" (čefurji) in Slovenia: "They are to be blamed for everything. Damn Serbs!" could very often be heard. But then, the protagonists of these accusations would realize the presence of Blažo's parents and would quickly add: "But not you, you are different, you are adjusted to our way of life". In those situations people would not try to apologize, or change

\footnotetext{
${ }^{13}$ During the 1960s and the early 1970s the practice in SFRY was such that the children were automatically given the citizenship of their fathers. If the family resided in the republic other than the one of the father's citizenship, parents would have been asked which citizenship they wanted for their child: the father's or the one of the country of residence. It seems that most of the families went with the automatic practice, conferring father's citizenship to their children. It is not clear which law regulated this practice and when and why it gave way to the later practice of registration of all children in the republics of their birth.
} 
their words, on the contrary, they would reconfirm their statement, only making it clear that "not-quite-real Serbs/Bosnians", or those who "practically became" Slovenes are left out of the "analysis".

Of course, this is typical for many people with prejudices: they would not abandon them even in the presence of people who contradict them. Contradictions are an inherent part of stereotypes and prejudices. But this "permissive" attitude may have sprung out of the fact that this particular "Bosnian Serb" family had Slovene citizenship. Testimonies of the erased do not mention such selective stereotyping. Maybe citizenship, as a formal "confirmation" of our belongingness, influences the degree to which others accept us as being a part of "their world".

\section{b) Perceptions of kin societies: moving to states we "belong" to}

Now I want to proceed with a slightly different type of narratives where citizenship emerges both as a question of papers and rights, and as an issue of the community we feel we belong to.

Sarajevo was the place in which I explored the theme of kin-state migration. It is definitely not the only city to attract such migrations, but seemed interesting to investigate because of a few different stories I heard in relation to the subject matter. Here I will compare two different cases of post-war migration to a perceived kin state.

Amra has a very peculiar life story. She is of Bosniak origin - her parents are originally from Sandžak - but was born and raised in Kosovo. She married a Kosovo Albanian and they lived, together with their two sons in North Kosovo. Their life was very ordinary until war in Kosovo began, and they suddenly found themselves in an unfavourable position. They lived in the Serb dominated area, with Amra's family living in the southern part. They had an Albanian family name, her husband and her sons had Albanian first names, but she and her sons spoke only Serbian - it was the only language spoken in the family. She was a teacher in a school where the majority of students were Serbs, and her sons went to a similar school. They lived among Serbs, but because of their family name were considered Albanian. They could not move to the southern - Albanian dominated - part of the city, because they spoke only Serbian. Things went from bad to worse when her older son began his studies in Serbia and during his first year - which coincided with the year war started in Kosovo - experienced humiliation and bullying because he came from Kosovo. The threats were coming from all sides, and finding their position intolerable - Bosniak-Albanian family from Kosovo that speaks only Serbian - they decided to leave their hometown and move into another country. The place they decided to go was Sarajevo - because Amra had some family members there, and it seemed in a way to be the place closest to the idea of home - a place where the majority of Bosniaks lived and where they shared a spoken language (Bosnian/Croatian/Serbian). 
They came with the documents of the Republic of Serbia - the only documents Amra still possesses. They registered as refugees - they came shortly after the bombing of 1999 - and even got permission from the UN to seek asylum in a third country based on the fact that they were a mixed marriage family. "An absurd thing in the first place", Amra said to me. "We never before thought of ourselves as being a mixed couple: we were born in the same town, he mainly spoke Serbian in his household, I spoke Serbian; Serbs in Kosovo saw both of us as Muslims, so we were the same to them as well...". They declined the offer due to her husband's ill health which deteriorated soon afterwards and almost a year after their move to Sarajevo, Amra found herself alone with her sons, holding statuses of refugees. They could not hold these statuses for a long time, and after a couple of years they had to apply for temporary residences in Bosnia and Herzegovina.

Now it has been fourteen years since they came to Sarajevo, and Amra said they do not feel integrated or accepted, especially her. The barriers were many, mainly the fact that they came from Kosovo and as she explained to me, "People here do not like us very much; they think we are intruders, that we do not really belong here". The greatest irony is that the single most significant obstacle to their integration and acceptance is again - the language. Namely, they speak the ekavica ${ }^{14}$ version of BCS language and majority of people in Sarajevo "recognize" them by their accent as coming from - actually - Belgrade! That cemented Amra's feeling of being cut from all the communities she was supposed to belong to - she is Bosniak from Kosovo which does not go down well with the Serb community in M., her birth town; she speaks only Serbian, thus her life in Kosovo is impossible, but on the top, she speaks ekavica which identifies her with Serbs from Serbia, and that is not conducive to integration in post-war Sarajevo.

Her sons received Bosnian citizenship after nine years of living and studying in Sarajevo. She was denied citizenship because she could not prove she could support herself financially - in other words, because she could not find a job. She is a teacher with good qualifications, and as she reassured me, there were many open positions for teachers, but they never wanted to hire her because of her dialect and accent. Her only citizenship document is still the Serbian passport, but the one which cannot secure her visa-free travel, because her official residence is in Kosovo. ${ }^{15}$ She received her passport via Belgrade, but on the other hand she has been having difficulties in obtaining ID from M., because - as Amra claims - Serbian authorities there are preventing Albanians (in her case, this designation might well be put under

\footnotetext{
${ }^{14}$ BCS, or Bosnian/Croatian/Serbian are considered to be one and the same language, with various dialects, which do not pose obstacles for people from Bosnia, Croatia, Serbia and Montenegro to understand each other. The most observable difference is the use of ekavica - typical for most parts of Serbia-or ijekavica, spoken in Croatia, Bosnia and Montenegro.

${ }^{15}$ Kosovo residents were not included in the Schengen visa liberalization regime applied to Serbia in December 2009. "According to the EU's stance, since it could not exercise control over the territory, the Serbian Ministry of Interior was not in a position to issue biometric passports to Kosovo residents required for the visa-free travel into the Schengen space." (Vasiljević 2012: 332).
} 
inverted commas) from registering and having official documents. She said that in her case the Belgrade authorities even intervened, but in vain. For that reason, she rarely travels to her birth town, despite the fact that she owns a property there and her mother still lives in the old family house.

Sarajevo is a major destination for Bosniaks from different places, especially from the Sandžak area, the region divided between Montenegro and Serbia where a significant Bosniak population lives. There are said to be some 20,000 inhabitants of Sarajevo originally coming from the town Pljevlja, which is only one small municipality in the Montenegrin part of Sandžak, comprising itself around the same number of inhabitants.

I met and talked with couple of Pljevljaks living in Sarajevo, including Mujo who is a very prominent figure in the organization - a cultural centre - assembling Pljevljaks living in Sarajevo. As they explained me, the Centre gathers three generations of Sarajevo Pljevljaks. Sarajevo has always been, as they explained further, a centre of gravitation for people from Sandžak. It was quite normal, even during socialist Yugoslavia, for people from that region to go to study either to Belgrade - where the majority of the Orthodox Sandžak population went, or to Sarajevo - where Bosniaks, or Muslims as they were officially called back then, opted to go. Mujo himself studied in Sarajevo just like most of his friends, although he returned to his hometown, and decided to move to Sarajevo only after the wars of the 1990s. Most of the people from Sandžak I talked to came to Sarajevo during and after 1999 (the bombing of Serbia and Montenegro). The reasons for coming were mostly socio-economic: a search for better life opportunities, expectations from the bigger city, and the major "bonus" was, of course, that all of these newcomers had relatives or friends, already living in Sarajevo, whom they could turn to for help. Mujo also added another thing: "During the 1990s, the national prefix was also accentuated and important".

Sarajevo, thus, during the 1990s became, even more than before, an attractive destination for Bosniaks of the region. Additionally, people were more encouraged to move and settle there, knowing that great number of their relatives, friends, and compatriots were already there, forming a small Sandžak, or even small Pljevlja citizenry in another country. This is important to stress because these already existing communal ties made the stories of Pljevljaks so much more different to the one of Amra. Although Pljevljaks are stressing that local prejudices against them exist as well, it was indicative that none of my interviewees experienced anything similar to Amra's case - both in terms of feelings of acceptance and of formally regulating their citizenship statuses. As for the former, obviously there was a big community to reduce possible exclusions from the society, and outside of that social "safety net", was the general feeling that Sarajevo is the city were Bosniaks are welcomed. As for the latter, having a social community that is anchored in more than three generations of compatriots is tantamount to already belonging to a certain citizenry of its own. None of my collocutors had any major issues with obtaining their documents and regulating their statuses. As Mujo said: "I was very familiar 
with the procedures, I knew many people, knew exactly who to contact, what to do... When you work in business and you know a lot of people, you know how to get things done more easily and quickly". This is not to imply that he received his documents in any other way than according to the law, just that his contacts enabled him to arrange everything with ease and as quickly as possible.

The role of the cultural centre he is involved in fulfils the same role: "the centre promotes Pljevlja's culture, maintains economic and cultural ties with Pljevlja city... but also enables Pljevljaks who move to Sarajevo to have a formal institution they can turn to, where they can seek help, and their compatriots are there to help them". This suggests that the "kin state magnetism" is not all about the ethnic "prefix" of a state or region and a "natural" inclination to migrate where our "coethnics" live, but is also very much related to our possibilities to accommodate, with relative ease, our citizenship rights and claims in the environment where we are already perceived as co-citizens, not necessarily by the state itself, but by a group large enough to constitute a sort of citizenry of its own.

\section{c) Kafkaesque situations}

Here I want to present yet another story of a migrant in Sarajevo, although this is not the case of a "kin state migration", and the accent is not so much on belonging as it is on the procedural entrapments we may fall into when living between two mutually incompatible citizenship regimes.

Artan is an Albanian from Pristina, who came to Sarajevo in 2001 to finish his studies and pursue his artistic career. His decision to move came after an unexpected offer to continue his professional development at the University of Sarajevo. The main obstacle for his full integration into Bosnian society was his poor knowledge of the language - he belongs to the younger generation of Kosovars who were schooled in parallel school systems, where Serbs went to official schools and learned in Serbian, and Albanian pupils studied in their own schools in Albanian. But, apart from that, being in Sarajevo surrounded with "artistic and cosmopolitan" friends, due to his profession, he never felt isolated or marked because of his origin; furthermore, he saw Sarajevo as "a part of this shared region, a part of the similar story".

But official citizenship policies do not share his vision. Knowing that BosniaHerzegovina does not recognize Kosovo as a sovereign state, and thus none of Kosovo's documents, I asked him about his status in Sarajevo and personal documents with which he travels and lives. His story of pursuing Bosnian citizenship had many Kafkaesque details. When he first arrived to Sarajevo, he did it with then valid documents for Kosovans, administered by the United Nations Interim Administration Mission in Kosovo - UNMIK). ${ }^{16}$ With those, he studied, declared

\footnotetext{
${ }^{16}$ After the bombing, on 10 June 1999, Kosovo was put under direct international administration in accordance with UN Resolution 1244. Officially, Kosovo residents remained Yugoslav citizens, but
} 
temporary residence, travelled back home, and finally even got employed shortly after graduation. But when Kosovo declared independence, UNMIK documents were no longer valid, and Artan quickly obtained his Kosovo passport. Due to the fact that B-H does not recognize Kosovo documents, he found himself in a problematic position, with no documents with which to prolong his working visa, or to travel from Sarajevo and back. Then he decided to take a Serbian passport: as a Kosovo citizen he was entitled to it, and the major bonus was that it would be a valid, recognized document in Bosnia proper. Furthermore, he decided to declare his address in Belgrade, not Pristina, so he could obtain a "visa-free" passport, which was of great importance to him, having to travel frequently in Europe due to his profession. ${ }^{17}$ It all went smoothly: he declared his residence in Belgrade, and got citizenship and regulated his position in Sarajevo.

But the real problems started when he decided to apply for Bosnian citizenship. At that moment he had already been living in Sarajevo for a couple of years, finished his studies there, had employment and lived with his Sarajevo partner. The first two times he made an application as "a person of cultural importance for the country", and he got rejected. The third time, he was fulfilling all the formal conditions, having lived there long enough, with properly prolonged working visas and residence permits. One of the conditions he had to fulfil - the usual one in the citizenship application process - was the official confirmation that he had not been convicted of any crimes and that he was not subject to any criminal charges. He obtained the confirmation from the Home Office in Belgrade where his Serbian residence was. But the procedure in Bosnia was such that the confirmation had to be issued from the place designated as the applicant's birth town in his valid Bosnian working visa - Pristina in Artan's case. That put Artan in an almost impossible situation: he could have gone to Pristina and ask for the confirmation, but it would have been issued as the official Kosovo document, which Bosnian authorities would not recognize. He turned to the Serbian authorities, who directed him to Niš - a town where Pristina residents' documents were held after 1999. But the Home Office in Niš told him they were unable to issue him this confirmation since the Serbian police had no presence or influence on Kosovo territory - after the Kumanovo agreement which concluded the Kosovo war back in 1999 - and, therefore, could not make any guarantees for Kosovo residents. In the end, the only document Artan could obtain from Serbia was confirmation from Belgrade that he had never been convicted and that he was not under any criminal investigation. To that was later added - after Artan explained his predicament to the officials in Serbia

UNMIK created a separate Central Civil Register of Kosovo that regulated residency status and issued travel documents to Kosovo residents.

${ }^{17}$ Another reason was that, had he applied for his Serbian passport as living in Pristina, he would have had to go actually to Niš to gather his documents. This is due to the fact that after the war in Kosovo, Serbian officials removed all the personal data of resident from Kosovo to different municipalities in Serbia. For instance, documents of Pristina residents are located in Niš. 
- the statement that this document should be considered as valid for the whole territory of the Republic of Serbia.

Having exhausted all the possibilities, and having done the only thing possible in the situation, Artan returned to Sarajevo only to find out that his documents would not suffice, and that, as regulations clearly state, confirmation from the birth town was needed. His dire situation was ultimately resolved in a way many unsolvable situations end when bureaucratic requirements hit the wall (and if the applicant is lucky): his case was pushed forward by the discretionary power of an administrator.

Artan now has both Bosnian and Serbian passports. He is thankful that he can travel often to Kosovo because his family is unable to visit him, possessing only documents of a state B-H does not recognize.

Policies and administration have turned Kosovo and Bosnia into two separate worlds, functioning on seemingly incommensurable principles. But plain geography and, more importantly, mobility and ties people maintain will often prove differently. Artan concludes his story: "I feel like a citizen of Bosnia, meaning I want to participate in its social life, want to contribute to better living here. But I also want to do that in Kosovo. I live in Bosnia, but I feel as belonging to both societies. These are all small worlds, even small markets if you want to think of it in that way; we have to think bigger than our small states we live in".

\section{d) Arbitrariness of belonging: between personal and official imaginaries of citizenship}

Marija is 88 years old, and has been living in Belgrade ever since the Second World War ended, but for the past couple of years has been struggling - with no results - to obtain Croatian citizenship. She told me her story in a very emotional way. She was born in a small place near the famous national park Plitvička jezera (Plitvice Lakes Park) in what was then Kingdom of Yugoslavia and what is now the Republic of Croatia. All her family members were Serbs from Croatia. When she was 15 - the war had just begun - she witnessed Ustashas ${ }^{18}$ massacring her mother and siblings, managed to escape and quickly afterwards joined the Partisan movement. As a young communist cadre she was sent immediately after the war to Belgrade, where she married and continued her life. She was regularly visiting her birthplace - where the family house and family owned land remained - up until the wars of the 1990s. When the war in Croatia ended Marija decided to check her status in now independent Croatia, to secure her family possessions and property, to sell them or to give them as inheritance to her children and grandchildren. But she was very unpleasantly surprised when her citizenship request was denied. She kept on insisting on her right to Croatian citizenship and regularly visited Croatian embassy in Belgrade. The answer was always negative.

\footnotetext{
${ }^{18}$ Croatian fascists from Wold War Two.
} 
According to current laws on citizenship in Croatia, applicants' claims of citizenship based on previously existing ties with Croatia must be substantiated with a document proving that the applicant has indeed been considered a Croatian citizen at any time in the past. Usually, confirmations from the birth registry or citizenship registry are required. The problem for Marija is that such registries for the Republic of Croatia did not exist before the Second World War, that is, during the period of a unitary Yugoslav Kingdom when there was no Republic of Croatia. Current Croatian laws do not recognize previously existing ties with the territory of Croatia as a legitimate basis for granting someone Croatian citizenship. As Marija moved to Belgrade and lived there ever since the establishment of the new Socialist Yugoslavia after the WW2, she was registered in the Serbian citizenship registry and had only Serbian republican citizenship.

However, this is very hard to explain to Marija, who due to her old age and emotional attachment to the place of her childhood and family origin, cannot fully grasp any argument denying her what she understands to be her inalienable right. "There I have a house, I have a land, what can I do with it as a foreigner? I was born there, suffered there immensely, and the only right thing would be to let me have that place again and offer it to my grandchildren as a piece of my memory".

Her story, which is essentially a story of conflicting views between personal and state-legal definition of a "genuine link" between an individual and a state, could be interestingly compared with another story, which has a completely different turn, but shares the same motif of having/losing/finding this genuine link (again with the Republic of Croatia).

Ana is from Belgrade but has been living in the UK for the past ten years. She came to the UK with a Serbian passport. Ana has a very complicated relationship with Serbia, where due to certain political and personal feuds, she almost lost her nationality. The details of her story are not significant in this context, but the important element is that she was unable to renew her Serbian passport (due to an on-going judicial dispute at a Serbian court), which consequently left her in the UK without a valid passport, the right to travel, without a proof of nationality, thus with no right to find a job, secure some other basic rights etc. In desperation, Ana turned to an option which did not look promising at first, but was worthwhile trying. Namely, she remembered that while she was still living in Belgrade and preparing to get married, she was actually holding Croatian republican citizenship - even though she had been born and had lived all her life, together with her family, in Belgrade ${ }^{19}$. The reason she had it was the already mentioned practice from the 1960s and the early 1970s of registering newborns with the republican citizenship registers of their fathers. Ana's father was indeed born in Croatia and had Croatian republican citizenship, which she was given upon her birth. Ana was advised that finding a

\footnotetext{
${ }^{19}$ In spite of that, when she first applied for passport in Serbia (quite late in her life), she had to complete a separate procedure and was eventually entered into the registry of Serbian citizens and became Serbian citizen.
} 
solid proof that she once held Croatian republican citizenship could secure her case. She first contacted the Croatian municipality her father was from, but they told her that all the documents from their registry had been destroyed during the war in Croatia (1991-1995).

Then she applied for Croatian citizenship with her marriage documents from Serbia stating she previously had held Croatian republican citizenship. The Croatian Ministry of the Interior needed to know on what basis the authorities of the Republic of Serbia once had considered her a Croatian citizen. The document she got married with - the only one she ever had, proving she was registered in the citizens' register in a municipality in Croatia - was to her misfortune quite problematic. Namely, it was issued during the war in Croatia, when the municipality her father was from and where she was registered upon her birth as well - was under the control of Serb rebel forces and their quasi-state "Republic of Serbian Krajina". Her citizenship certificate came as the official document of that short-lived entity, unrecognized by Croatia, and as such would be completely useless, even counterproductive for her case. The only option she was left with, as lawyers told her, was the following one. As it was already mentioned about the practice of registering children with their fathers' citizenship in SFRY, if the family lived in a republic different from the one of the father's citizenship, the family would be asked which citizenship to confer on their child: the one of the place of residence or the father's. Sometimes, this family's consent would be signed on a special form. If Ana could find that document, she would have proof that she had been registered as a Croatian citizen.

Surprisingly enough, her parents in Belgrade managed to find the document in the Archive of the Republic of Serbia. Basically, it was a simple form where her parents gave consent for their child to be entered in the Croatian registry of citizens. This document alone - and a skilful lawyer - finally resolved Ana's practical statelessness. She received Croatian citizenship and passport, and to her great relief, was able to move on with her life in the UK.

Both Marija's and Ana's quest for citizenship was motivated by a dire personal need - albeit of a different origin in each case - and both cases were resolved in relation to the existence of the "genuine link", or a lack thereof. But they also clearly show the discrepancy between the personal and the legal-procedural definitions of the genuine link with a community. Belonging to a political community involves different levels of imaginaries - some being rooted in personal experiences and others in the state legislature - and they do not necessarily overlap. This leaves the relation between the identitarian and the formal-legal aspect of citizenship always open and susceptible to different interpretation.

But the question of belonging does not concern only the individual who "wants to belong" on the one hand, and the state which "confirms" this belonging on the other. Our belongingness is always mediated, shaped by, sometimes defined and judged by the others with whom we are supposed to belong together. This becomes even more obvious and decisive in times when "rules of belonging" are being 
redefined, and "degrees of belonging" begin to define one person's place in a social universe. The following story illustrates one such situation.

e) Belonging in the eyes of others

Amra's story already points to the absurd importance of external (quasi) markers of belonging and identity. Her language or rather, the dialect in which she speaks led many to assume (incorrectly) what her background and ethno-national identity were. She told me how at one point she had been trying to speak ijekavica with a Bosnian accent too, but the attempt had only resulted in her breakdown, after which she even sought psychological counselling. She was told that learning an altogether new language would be a much easier task than learning to speak her own in a different manner, especially at her age.

I heard a similar story about the struggle of "overcoming" one's accent and dialect, in order to be accepted, from a woman who came to Serbia in 1991 as a refugee from Croatia. She escaped with her three year old daughter to her husband's family, who lived in a small town in southern Serbia. Even though she found herself among her in-laws and neighbours she knew from before (as the family used to pay regular visits to the town before the war), given the new context - war in Croatia and probably given the fact that she came from the "mixed" family, of Croatian mother and a Serb father, everyone in her surrounding expressed their anger and frustration over the fact that she "still" spoke "Croatian". They expected her to "adapt" and to raise her daughter in Serbian, that is, in ekavica. "To them, I was no longer the person whom they knew from before, when we used to come every summer and to spend wonderful time together. It was as though I became someone else, someone hostile, not deserving of sympathy and understanding."

This motif of "features-of-belonging assessment" and consequential "categorization" was painfully experienced by many during the wars in Yugoslavia, especially by those who could not be easily "counted in" in new dominant communities of belonging and who, additionally, found themselves in the middle of the armed conflict. The following story is greatly illustrative of this predicament and the consequences it had on personal lives.

Goran was born and lived in Croatia and was of mixed parentage, his mother being an ethnic Croat and his father an ethnic Serb. When the first conflicts of 1991 began in Croatia the family was instructed to move because they were in danger, especially Goran's father. They moved to their relatives in a part of Croatia dominated by Serbs. Again, warnings came, this time because of Goran's Croatian mother and the family decided to move again, this time to Serbia where Goran's aunt lived. Not long after they arrived in Serbia their presence was denounced by the neighbours who told the police that "ustasha extremists" had moved in next door. Police came and took special interest in Goran, who was at the time in his midthirties, questioned him the whole night, and threatened they would send him to the front line in Croatia. Realizing that with his background he was safe neither in 
Croatia nor in Belgrade (and being in the age suitable for army recruitment), Goran decided to move yet again, to his other relatives who lived in a major town in Bosnia and Herzegovina (that was at that time still peaceful).

Unluckily it was only a couple of months before the war started in Bosnia too. Being afraid to leave either for Serbia or for Croatia and later unable to move from that city due to the war, he stayed in Bosnia. However, even there, being of both Serb and Croat origins, he found himself in an unfavourable position since the city was under Bosniak control. This time it was precisely the documents that began to play some part in his "categorization", and luckily for him, in a good way. First, he escaped recruitment in Bosnia by showing his Croatian birth certificate, and later, when he finally managed to escape Bosnia, he was granted Bosnian refugee status in another country, based on his Bosnian ID, which he managed to secure during his first months of residing in Bosnia.

Goran's case shows the fragility of our social relations and of our embeddedness in communities we (think we) belong to. Our belongingness is mediated by our family circumstances, the political context, actors we encounter, and finally, but not least importantly, by the documents that at a given moment we have, or in some cases, do not have.

\section{Conclusion}

It is hard to make any conclusive remarks about the different stories I have presented. They are but a small fraction of the stories of those who lived through the breakup of Yugoslavia, personally experiencing what it means to officially belong to a community, to have the "right to have rights", to have valid documents or to be denied of all of the above. When citizenship regimes change and when we get caught in their transition or are forced to transit from one regime to another, we truly live citizenship in all its meanings: we begin to epitomize our documents' values and relevance, we hit the walls surrounding our communities of belonging, our social ties and identities are put into question, and most of all, it becomes clear how all these issues are interconnected and mutually dependent. Moreover, these examples do not close or encircle any concrete argument; if anything, they open up questions and new possibilities of understanding the link between the legal, the political, the social and the personal aspects of citizenship.

However, I would like to stress one topic that kept emerging from the personal narratives and that is the question of belonging (as well as proofs of it, both official and unofficial) The reason for paying attention to it is that scholarly writing does not often problematize a slippery notion of belonging with reference to citizenship, just as citizenship is rarely reflected upon with regards to the experiences of belonging (how belonging is actually played out in people's lives).

First of all, we could see the instability of belongingness. It seems as if it relies on changing and unstable criteria. Different instances can guarantee it: the state, other co-citizens, political circumstances. Sometimes, we need an "official" proof of 
belonging to be accepted by others (in the form of a personal citizenship document), sometimes when we are deprived of it, we lose all communal ties and, indeed, we stop belonging, as if all our previous social relations depended on our documents without our realizing it (as in the case of the erased).

We also saw the discrepancy between the personal and state-official definitions of the genuine link with a community. Belonging thus involves different levels of imaginaries - personal, contingent, administrative, politically defined. They do not necessarily overlap, thus creating "gaps" in belonging, fractures between the emotional and the official, "the certified". Belonging is always (like citizenship) both a personal, individual experience and a socially or politically regulated status approved or denied.

Finally, when observing this nexus between belongingness and citizenship, as it appears in personal testimonies where boundaries between the documental and the social seem to be blurred, previously laid ideas about the interconnectedness of the personal and the subjective on the one hand and the legal and the political on the other, become even clearer. The documentality of citizenship does not belong solely to the objective world of regulations, policies, state mechanisms of control and management - it is very much lived and dependent on the social relations in which it is immersed. On the other hand, our social roles and positions, places we hold in our community of belonging - great parts of our subjective identities - are not only ideational in their nature, but very much dependent on documents and registrations that trace our existence in the social worlds we inhabit. 


\section{Bibliography}

Bauböck, R. (2010), „Studying Citizenship Constellations", Journal of Ethnic and Migration Studies, 36 (5), 847-859.

Bellamy, R. et al. (2004), Lineages of European citizenship: rights, belonging and participation in eleven nation-states. London: Palgrave.

Bonfiglioli, C. (2013), "Gendering Social Citizenship: Textile Workers in postYugoslav States", CITSEE Working Paper Series, School of Law, University of Edinburgh.

Brubaker, R. (1992), Citizenship and nationhood in France and Germany, Cambridge: Harvard University Press.

Brubaker, R. (1996), Nationalism Reframed, Nationhood and the national question in the New Europe, Cambridge: Cambridge University Press.

Dedić, J., V. Jalušić and J. Zorn (2003), The Erased. Organized Innocence and the Politics of Exclusion, Ljubljana: Mirovni Inštitut.

Deželan, T. (2012), "In the Name of Nation or/and Europe? Determinants of the Slovenian Citizenship Regime", Citizenship Studies 16 (3-4), 413-429.

Đorđević, B. (2013), "Politics of Return, Inequality and Citizenship in the PostYugoslav Space", CITSEE Working Paper Series, School of Law, University of Edinburgh.

Ferraris, M. (2013), Documentality. Why It Is Necessary to Leave Traces, New York: Fordham University Press.

Groebner, V. (2007), Who Are You? Identification, Deception, and Surveillance in Early Modern Europe, New York: Zone Books.

Isin, Engin F. \& Bryan S. Turner (2007), „Investigating Citizenship: An Agenda for Citizenship Studies", Citizenship Studies, 11:1, 5-17.

Jansen, S. (2009), "After the red passport: towards an anthropology of the everyday geopolitics of entrapment in the EU's 'immediate outside'", Journal of the Royal Anthropological Institute 15, 815-832.

Joppke, Ch. (2007), "Transformation of Citizenship: Status, Rights, Identity", Citizenship Studies, 11(1), 37-48. 
Kacarska, S. (2012), “Europeanisation through mobility: visa liberalisation and citizenship regimes in the Western Balkans", CITSEE Working Paper Series, School of Law, University of Edinburgh.

Kahlina, K. (2013), "Contested terrain of sexual citizenship: EU accession and the changing position of sexual minorities in the post-Yugoslav context", CITSEE Working Paper Series, School of Law, University of Edinburgh.

Koska, V. (2012), "Framing the Citizenship Regime within the Complex Triadic Nexuses: the Case Study of Croatia", Citizenship Studies 16 (3-4), 397-412.

Linde, C. (2009), Working the Past. Narrative and Institutional Memory, Oxford University Press.

Marshall, T. H. (1998), "Citizenship and social class", in: Gershon Shafir (ed.), The citizenship debates, Minnesota: University of Minnesota Press, pp. 93-111.

Navaro-Yashin, Y. (2007), "Make-believe papers, legal forms and the counterfeit: affective interactions between documents and people in Britain and Cyprus", Anthropological Theory 7, 79-98.

Neumayer, E. (2006), "Unequal access to foreign spaces: how states use visa restrictions to regulate mobility in a globalized world", Transactions of the British Institute of Geographers, 31 (1), 72-84.

Pejić, J. (1998), "Citizenship and Statelessness in the Former Yugoslavia: The Legal Framework, in: S. O'Leary and T. Tiilikainen (eds.), Citizenship and Nationality Status in the New Europe, London: The Institute for Public Policy Research/ Sweet \& Maxwell, 169-186.

Pocock, J. G. A. (1998), "The ideal of citizenship since classical times“, in: Gershon Shafir (ed.), The citizenship debates, Minnesota: University of Minnesota Press, pp. 3141.

Radović, M. (2013), "Citizenship and Religion in the Post-Yugoslav States", CITSEE Working Paper Series, School of Law, University of Edinburgh.

Rakić, V. (1998), “State Succession and Dissolution: The Example of FR Yugoslavia”, Croatian Critical Law Review 3 (1-2), 57-70.

Sarajlić, E. (2012), “Conceptualising citizenship regime(s) in post-Dayton Bosnia and Herzegovina", Citizenship Studies 16 (3-4), 367-381. 
Sardelić, J. (2013), "Romani Minorities on the Margins of Post-Yugoslav Citizenship Regimes", CITSEE Working Paper Series, School of Law, University of Edinburgh.

Shafir, G. (1998), "Introduction: The Evolving Tradition of Citizenship", in: Shafir, G. (ed.), The Citizenship Debates, Minneapolis, MN: University of Minnesota Press.

Shaw, J. and I. Štiks (2012), "Introduction: Citizenship in the New States of South Eastern Europe", Citizenship Studies 16 (3-4), 309-322.

Shaw, J. and I. Štiks (eds.) (2013), Citizenship after Yugoslavia, Routledge.

Soysal, Y. N. (1998), „Toward a Postnational Model of Membership“, in: Gershon Shafir (ed.), The citizenship debates, Minnesota: University of Minnesota Press, pp. 189-217.

Spaskovska, Lj. (2012), “The fractured 'we' and the ethno-national ' $\mathrm{I}$ ': the Macedonian citizenship framework", Citizenship Studies 16 (3-4), 383-396.

Stjepanović, D. (2012), “Territoriality and Citizenship: Membership and Sub-State Polities in Post-Yugoslav Space", CITSEE Working Paper Series, School of Law, University of Edinburgh.

Štiks, I. (2013), "A Laboratory of Citizenship: Shifting Conceptions of Citizenship in Yugoslavia and post-Yugoslav States", in: Shaw, J. and I. Štiks (eds.) (2013), Citizenship after Yugoslavia, Routledge, 15-37.

Torpey, J. (2000), The Invention of the Passport, Cambridge University Press.

UNHCR and Praxis (report) (2007), Analiza situacije interno raseljenih lica sa Kosova $\mathrm{u}$ Srbiji: zakon i praksa, http://www.infocentar.libergraf.rs/documents/Analiza\%20situacije\%20interno\%20ras eljenih\%20lica\%20sa\%20Kosova\%20u\%20Srbiji\%20-\%20zakon\%20i\%20praksa.pdf

Vasiljević, J. (2012), “Imagining and Managing the Nation: Tracing Citizenship Policies in Serbia", Citizenship Studies 16 (3-4), 323-336.

Wiener, A. (1994), "Citizenship Policy in a Non-State. Implications for Theory", A conference paper, 2nd ECSA World Conference on Federalism, Subsidiarity and Democracy in the European Union, Brussels, May 1994.

Wiener, A. (1999), „From Special to Specialized Rights: The Politics of Citizenship and Identity in the European Union", in: Michael Hanagan and Charles Tilly (ed.), Extending citizenship, reconfiguring states, Lanham, Meryland: Rowman \& Littlefield Publishers, Inc, pp. 195-227. 
Zaharijević, A. (2013), “Being an Activist: Feminist citizenship through transformations of Yugoslav and post-Yugoslav citizenship regimes", CITSEE Working Paper Series, School of Law, University of Edinburgh.

Žilović, M. (2012), “Citizenship, Ethnicity, and Territory: the Politics of Selecting by Origin in Post-Communist Southeast Europe", CITSEE Working Paper Series, School of Law, University of Edinburgh. 

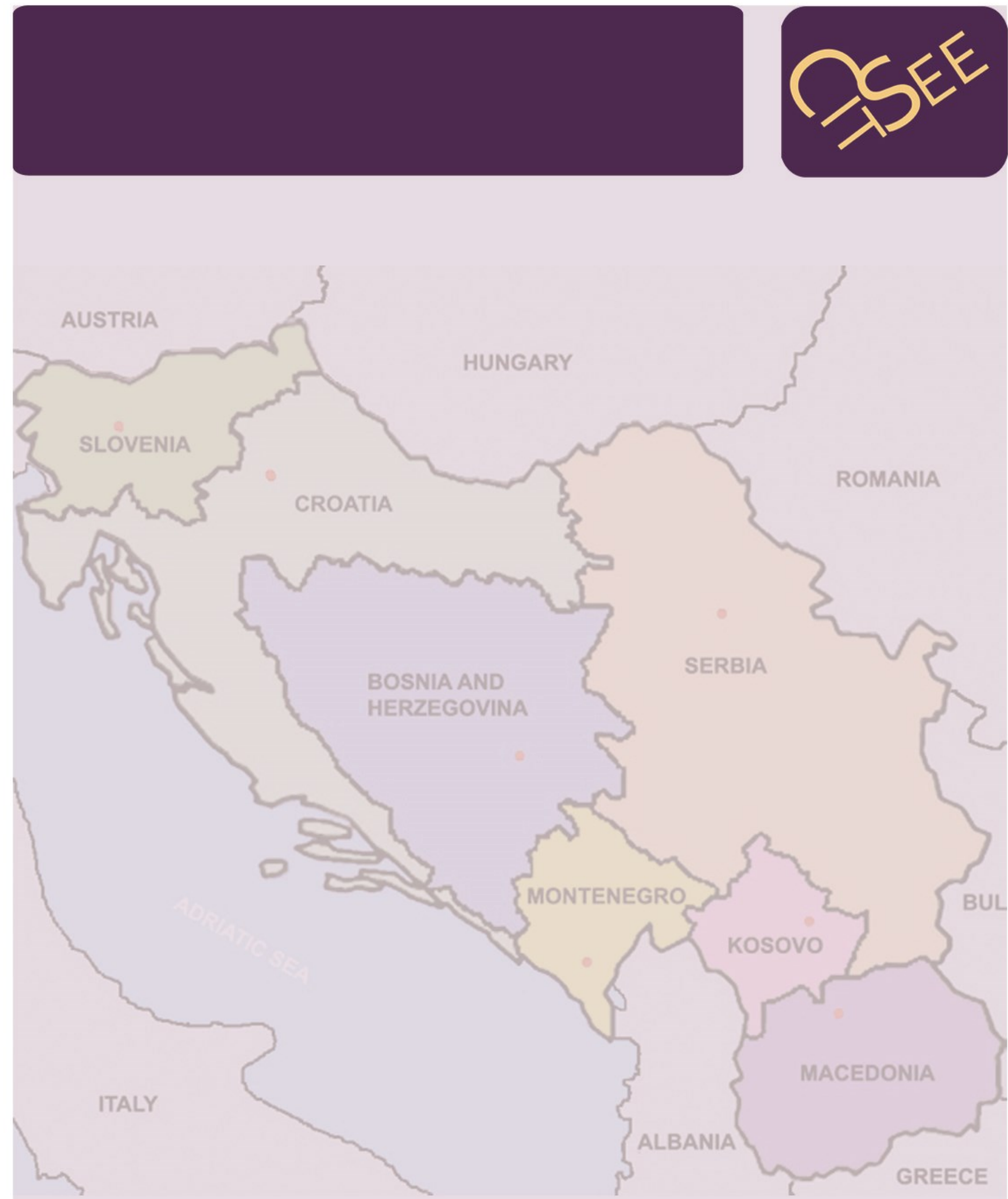

I S SN 2046-4096

The EuRopeanisation OF Citizenship in the SuCCESSOR States of the Former Yugoslavia (CitseE) SCHOOL OF LAW, THE UNIVERSITY OF EDINBURGH,

OLD COLLEGE, SOUTH BRIDGE

EDINBURGH, EH 8 GYL, SCOTLAND, UK

WWW, LAW, ED, AC, UK/CITSEE 